\title{
Attitudes and behaviours of physicians towards the relationship with the pharmaceutical industry in Saudi Arabia
}

Salman Bahammam, ${ }^{1}$ Suhail Asiri, ${ }^{1}$ Yassar Al-Jahdali, ${ }^{1,2}$ Salim Baharoon, ${ }^{1,2}$ Adnan Al Shaikh, ${ }^{1}$ Majed Al-Ghamdi, ${ }^{1,2}$ Abdullah ALharbi ${ }^{1,2}$ and Hamdan Al-Jahdali ${ }^{1,2}$

${ }^{1}$ College of Medicine, King Saud Bin Abdulaziz University for Health Sciences, Riyadh, Saudi Arabia. (Correspondence to: Salim Baharoon: baharoon@ hotmail.com). ${ }^{2}$ Department of Medicine, King Abdulaziz Medical City, National Guard Health Affairs, Riyadh, Saudi Arabia.

\begin{abstract}
Background: The relationship and interactions between physicians and the pharmaceutical industry can affect patient care. A physician's practice can be influenced by this relationship. It is believed that these interactions are common among doctors in Saudi Arabia.

Aims: This study was undertaken to assess the frequency of such relationships and physicians' attitudes and behaviours toward them.

Methods: This was a cross-sectional questionnaire survey completed by practicing physicians at four Saudi government and private tertiary care centres in Riyadh, Saudi Arabia. The questionnaire addressed the frequency of meetings with representatives of pharmaceutical companies (PRs) and of receiving gifts and considered the physicians' attitudes and behaviours towards PRs.

Results: A total of 300 completed questionnaires were obtained. Among the physicians surveyed, 223 (74.3\%) met PRs one to three times per month. Up to $191(64 \%)$ of physicians admitted receiving gifts. More than two thirds of physicians-192 (63\%) have been invited to activities sponsored by pharmaceutical companies. Among the physicians, 239 (80\%) agreed that PRs use promotional techniques in their approach and $251(84 \%)$ of them stressed the need for expert physicians to attend presentations by PRs to correct the facts.

Conclusion: The frequent meetings between physicians and PRs and the use of promotional techniques by PRs are concerning. Future studies should assess the impact of this involvement on medical practice and drugs prescription in Saudi Arabia. Keywords: Physicians; pharmaceuticals, physician, relationship, Saudi Arabia

Citation: Bahammam S; Asiri S; Al-Jahdali Y; Baharoon S; Al Shaikh A; Al-Ghamdi M et al. Attitudes and behaviours of physicians towards the relationship with the pharmaceutical industry in Saudi Arabia. East Mediterr Health J. 2020;26(3):323-330. https://doi.org/10.26719/emhj.19.024

Received: 01/08/17; accepted: 16/07/18

Copyright (C) World Health Organization (WHO) 2020. Open Access. Some rights reserved. This work is available under the CC BY-NC-SA 3.o IGO license (https://creativecommons.org/licenses/by-nc-sa/3.o/igo).
\end{abstract}

\section{Introduction}

Interactions between physicians and the pharmaceutical industry are widespread practice $(1,2)$. In the early 1950 s and 1960s, contacts between pharmaceutical representatives (PRs) and physicians were seen as a positive relationship; PRs were considered to be important sources of information for physicians. However, since 1980, these relationships have been subjected to major criticism and condemnation by many healthcare professionals. Physicians may be influenced, directly or indirectly, by the profit-seeking behaviour of pharmaceutical companies (3). There may be a conflict of interest between the physician's duty to the patient and the interests of the pharmaceutical industry, leading to the physician recommending or promoting certain products or drugs (4).

PRs, through their relationship with healthcare providers, may influence prescribing patterns and stimulate requests for the addition of drugs to hospital formularies. Wazna (2000) reported in Montreal, Canada that physicians met with PRs on average four times per month and residents accepted six gifts per year (5). Another survey, from the United States of America (USA) in 2001, reported $92 \%$ of physicians received drug samples, $61 \%$ received meals, tickets to events, or free travel, $13 \%$ received financial or other kinds of benefits, and $12 \%$ received incentives for participation in clinical trials (6).

Another recent study by Campbell EG et al. (7) surveyed more than 3000 physicians in the USA, and revealed that most physicians (94\%) reported some type of relationship with the pharmaceutical industry, and most of these relationships involved receiving food in the workplace $(83 \%)$ or receiving drug samples $(78 \%)$. More than one third of the respondents $(35 \%)$ received reimbursement for costs associated with professional meetings or continuing medical education, and more than one quarter $(28 \%)$ received payments for consulting, giving lectures, or enrolling patients in trials (7).

Another study also reported that physicians are now meeting more frequently (up to 16 meetings per month) with PRs than the average of 4.4 meetings per month (5). This increase in the number of visits and the closer relationship raise concerns regarding violations of professional codes of ethics. Recently, many studies and reports have been published confirming industry influence on the objectivities and behaviors of physicians 
(8-16). Many physicians frequently do not recognize that their decisions have been affected by commercial gifts and services and may in fact deny or minimize such influence. The continuing increase in the influence of industry on physicians' practice, research and education has prompted the American College of Physicians to issue a statement addressing industry relations with individual physicians and medical professional groups (17).

We have observed that the relationship between physicians and the pharmaceutical industry is increasing in Saudi Arabia. However, we are not certain of the extent of this relationship and the physicians' attitudes towards it. Therefore, this study has been designed to assess the attitudes and behaviours of physicians toward their relationship with PRs.

\section{Methods}

\section{Study subjects}

This is a cross-sectional survey conducted from March to September 2015. The study sample comprised physicians of all ranks and different specialties from three governmental tertiary care hospitals and one private tertiary care hospital in Riyadh, Saudi Arabia. The physicians were recruited after conferences and academic clinics or activities. Physicians were divided into five groups based on their specialties or subspecialties. These groupings were internal medicine, surgery, obstetrics and gynaecology, paediatrics and others (including family medicine). Positions of physicians were identified as consultants, non-consultants and in training. Non-consultants were defined as associate consultants, assistant consultants and staff physicians. The in-training groups comprised fellows, residents and medical interns. Years of experience were taken as more or less than 15 years. Ethical approvals were obtained from the participating hospitals and the identities of the subjects were kept anonymous. Informed consent was obtained from participants taking part in the study. The sample size required was estimated to be 325 physicians for a confidence level of $95 \%$, and a predicted positive response of 0.25 based on previous studies (16).

\section{Questionnaire}

The questionnaire was developed based on published literature (Saito et al.) to explore the relationship between physicians and pharmaceutical companies (16). The survey consisted of 39 questions covering demographic data, frequency of meetings with PRs, receiving gifts from PRs, the physicians' attitudes and behaviours towards PRs and the medical knowledge gained from the meetings.

The questionnaire addressing the physicians' attitudes and behaviours used a Likert scale: 1-agree, 2-neutral, or 3-disagree with the statements. Individual physicians were visited in their offices and on the wards and the questionnaires completed immediately. The questionnaires were in English as all physicians in Saudi Arabia speak English.

\section{Statistical analysis}

Comparisons between categorical variables were performed using Chi-square and statistical significance was set at $P$-value $<0.05$. Years of practice was categorized into $>15$ years and $<15$ years. The Statistical Package for Social Sciences software (SPSS 21.0, Chicago, IL, USA) was used for the analysis.

\section{Results}

During the study period 514 questionnaires were distributed and 325 questionnaires returned, giving a response rate of $63.2 \%$. Twenty-five of these were excluded owing to incomplete data and a total of 300 questionnaires were analyzed. The majority of the participants, 219 $(73 \%)$ were of Saudi nationality, 155 (52\%) were consultants and $176(58 \%)$ of all physicians were from internal medicine (Table 1).

\begin{tabular}{|c|c|}
\hline & No (\%) \\
\hline \multicolumn{2}{|l|}{ Gender } \\
\hline Male & $231(77)$ \\
\hline Female & $69(23)$ \\
\hline \multicolumn{2}{|l|}{ Nationality } \\
\hline Saudi & 219(73) \\
\hline Non-Saudi & $81(27)$ \\
\hline \multicolumn{2}{|l|}{ Hospital setting } \\
\hline Private hospital & $40(13.3)$ \\
\hline Government hospital & $260(86.7)$ \\
\hline \multicolumn{2}{|l|}{ Institution } \\
\hline Academic & $242(80.7)$ \\
\hline Non-academic & $58(19.3)$ \\
\hline \multicolumn{2}{|l|}{ Year of practice } \\
\hline Less than 15 & $131(43.7)$ \\
\hline 15 or more & $169(56.3)$ \\
\hline \multicolumn{2}{|l|}{ Position of physician } \\
\hline Consultant & $155(51.7)$ \\
\hline Non-consultant & $64(21.3)$ \\
\hline In-training & $81(27)$ \\
\hline \multicolumn{2}{|l|}{ Specialties } \\
\hline Internal medicine & $176(58.7)$ \\
\hline Pediatrics & 35(11.7) \\
\hline Obstetrics/gynecology & $19(6.3)$ \\
\hline General Surgery & $40(13.3)$ \\
\hline Others & $30(10)$ \\
\hline
\end{tabular}




\section{Attitudes and behaviours of physicians towards pharmaceutical representatives (PRs)}

A majority of physicians $(190,63 \%)$ agreed that pharmaceutical companies played an important role in supporting continuing medical education (CME) in their institute. On the other hand, 139 (46\%) of physicians stated that PRs did not have a teaching role in their institute and $136(45 \%)$ felt that PRs should not be banned from giving lectures. Pharmaceutical companies were acknowledged to support speakers at conferences $(234,78 \%)$. However, $239(80 \%)$ believe that PRs use lecture time to advertise their products and $251(84 \%)$ believed that it is necessary to have expert faculty attending such lectures to redress the balance.

Over three quarters of respondents $230(77 \%)$ had received no training, whether at medical school or later, on how to interact with pharmaceutical companies and their representatives. Out of the participants, 135 (45\%) and $142(47.3 \%)$ agreed that the information supplied by the PRs regarding both new and old drugs was accurate. Nevertheless, $184(61 \%)$ stated that discussions with PRs and gifts received did not have any impact on their prescribing behavior. However, 116 (39\%) stated that such discussions and interactions influenced the prescribing behavior of other physicians (Table 2).

\section{Meetings and receiving of gifts from pharmaceutical representatives (PRs)}

Physician exposure to PRs was very frequent, occurring one to three times per month, and $223(74 \%)$, and 147 (49\%) physicians had received drug samples up to three times monthly.
More than half of the physicians (60.3\% and 55.3\%) received stationery and industry sponsored CME events within the workplace from one to three times per month (Table 3).

\section{Comparison between categorical variables}

Demographic variables, including sex, nationality, years of experience, position held, specialty, type of hospital (governmental or private, academic or non-academic) were considered and categories compared. Table 3 shows that more physicians with 15 years of experience or more $(156,92 \%)$ had regular meetings with PRs and invitations to industry sponsored CME events. In addition, while meetings with PRs are commonplace, significantly more physicians working in private hospitals $(37,93 \%$ ) had regular meetings with PRs than was seen in government hospitals $(211,82 \%)(P=0.014)$. Similarly, drug samples were given to more physicians in the private sector than in government hospitals; 39 (98\%) compared with 116 (45\%) respectively $(P<0.001)$. Most government physicians believe that PRs employ marketing techniques in their approach; 220 $(85 \%)$ compared to $19(48 \%)$ of private sector physicians $(P<$ $0.001)$. Only $100(38 \%)$ of the government physicians compared to $35(88 \%)$ of private sector physicians believed that the information provided by PRs was accurate $(P<0.001)$. Table 4 shows statistically significant changes in prescribing behaviour between experienced and less experienced physicians, with 123 (73\%) experienced physicians believing that their prescribing behaviour was not impacted after meetings with PRs, compared to 61 (47\%) less experienced physicians $(P<0.001)$. The information provided and any gift given to the physician was related to the influence of PRs on prescribing behaviors.

\begin{tabular}{|c|c|c|c|}
\hline Parameters & $\begin{array}{l}\text { Agree } \\
\text { N (\%) }\end{array}$ & $\begin{array}{c}\text { Neutral } \\
\text { N (\%) }\end{array}$ & $\begin{array}{c}\text { Disagree } \\
\mathbf{N}(\%)\end{array}$ \\
\hline \multicolumn{4}{|l|}{ Attitude of physicians towards PRs } \\
\hline PR plays important role in CME for physicians & $190(63)$ & $50(17)$ & $60(20)$ \\
\hline PR perform important teaching function & $78(26)$ & $83(28)$ & $139(46)$ \\
\hline PR should be banned from presentation in hospitals & $79(26)$ & $85(28)$ & $136(45)$ \\
\hline I was given sufficient training during my pre and post graduate training on interacting with PR & $42(14)$ & $28(9)$ & $230(77)$ \\
\hline PR supports important conferences and speakers. & $234(78)$ & $44(15)$ & $22(7)$ \\
\hline PR employs marketing techniques in their interactions & $239(80)$ & $46(15)$ & $15(5)$ \\
\hline An expert faculty member should be present at all presentation by PR & $251(87)$ & $35(12)$ & $14(5)$ \\
\hline \multicolumn{4}{|l|}{ Behaviors of physicians towards PR } \\
\hline PR provides accurate information about new medications & $135(45)$ & $62(21)$ & $103(34)$ \\
\hline PR provides accurate information about old medications & $142(47)$ & $83(28)$ & $75(25)$ \\
\hline Discussion with PR have an unfavorable impact on my prescription behaviors & $75(25)$ & $41(14)$ & $184(61)$ \\
\hline Gifts from PR have an unfavorable impact on my prescription behaviors regardless of the monetary value & $76(25)$ & $42(14)$ & $182(61)$ \\
\hline Gifts from PR have an unfavorable impact on other physicians' prescription behaviors regardless of the monetary value & $116(39)$ & $93(31)$ & $91(30)$ \\
\hline I would have some degree of contact with PR weather or not promotional gifts were given & $183(61)$ & $67(22)$ & $50(17)$ \\
\hline It is appropriate to receive gifts of low monetary value from PR & $65(22)$ & $57(19)$ & $178(59)$ \\
\hline It is appropriate to receive gifts of high monetary value from $\mathrm{PR}$ & $39(13)$ & $35(12)$ & $226(75)$ \\
\hline
\end{tabular}




\begin{tabular}{|c|c|c|c|c|c|c|c|c|}
\hline \multirow[t]{2}{*}{$\mathbf{N}(\%)$} & & \multirow[t]{2}{*}{ Total } & \multicolumn{2}{|c|}{ Years of Experience } & \multirow{2}{*}{$\begin{array}{c}P \\
\text { value }\end{array}$} & \multicolumn{2}{|c|}{ Hospital Affiliation } & \multirow{2}{*}{$\begin{array}{c}P \\
\text { value }\end{array}$} \\
\hline & & & $\begin{array}{c}<15 \text { years } \\
(N=131)\end{array}$ & $\begin{array}{c}>15 \text { years } \\
(\mathrm{N}=169)\end{array}$ & & $\begin{array}{c}\text { Private } \\
\text { Hospital } \\
(\mathbf{N}=40)\end{array}$ & $\begin{array}{c}\text { Governmental } \\
\text { Hospital } \\
(\mathbf{N}=\mathbf{2 6 0})\end{array}$ & \\
\hline \multirow{3}{*}{$\begin{array}{l}\text { Average } \\
\text { meetings with } \\
\text { pharmaceutical } \\
\text { rep (PR) }\end{array}$} & Never & $52(17)$ & $39(30)$ & $13(8)$ & \multirow{3}{*}{$<.001$} & $3(8)$ & 49 (19) & \multirow{3}{*}{.014} \\
\hline & Once to three times a month & $223(74)$ & $88(67)$ & $135(80)$ & & $37(93)$ & $186(72)$ & \\
\hline & One a week or more & $25(8)$ & $4(3)$ & $21(12)$ & & 0 & $25(10)$ & \\
\hline \multirow[t]{3}{*}{ Drug Samples } & Never & $145(48)$ & $74(56)$ & $71(42)$ & \multirow{3}{*}{.045} & $1(3)$ & $144(55)$ & \multirow{3}{*}{$<.001$} \\
\hline & Once to three times a month & $147(49)$ & $54(41)$ & $93(55)$ & & $39(98)$ & $108(42)$ & \\
\hline & One a week or more & $8(3)$ & $3(2)$ & $5(3)$ & & 0 & $8(3)$ & \\
\hline \multirow{3}{*}{$\begin{array}{l}\text { Stationery such } \\
\text { as pens and } \\
\text { notepads }\end{array}$} & Never & $109(36)$ & $62(47)$ & $47(28)$ & \multirow{3}{*}{.002} & $6(15)$ & $103(40)$ & \multirow{3}{*}{.008} \\
\hline & Once to three times a month & $181(60)$ & $65(50)$ & $116(69)$ & & $33(83)$ & $148(57)$ & \\
\hline & One a week or more & $10(3)$ & $4(3)$ & $6(4)$ & & $1(3)$ & $9(3)$ & \\
\hline \multirow{3}{*}{$\begin{array}{l}\text { Industry- } \\
\text { sponsored CME } \\
\text { events inside } \\
\text { the workplace }\end{array}$} & Never & $108(36)$ & $70(53)$ & $38(22)$ & \multirow{3}{*}{$<.001$} & $14(35)$ & $94(36)$ & \multirow{3}{*}{.299} \\
\hline & Once to three times a month & $17859)$ & $59(45)$ & $119(70)$ & & $26(65)$ & $152(58)$ & \\
\hline & One a week or more & $14(5)$ & $2(2)$ & $12(7)$ & & 0 & $14(5)$ & \\
\hline \multirow{3}{*}{$\begin{array}{l}\text { Meals outside } \\
\text { the workplace }\end{array}$} & Never & $158(52)$ & $86(66)$ & $72(43)$ & \multirow{3}{*}{$<.001$} & $9(23)$ & 149 (57) & \multirow{3}{*}{$<.001$} \\
\hline & Once to three times a month & $96(32)$ & $40(31)$ & $94(56)$ & & $31(78)$ & $103(40)$ & \\
\hline & One a week or more & $4(1)$ & $5(4)$ & $3(2)$ & & 0 & $8(3)$ & \\
\hline \multirow{3}{*}{$\begin{array}{l}\text { Industry- } \\
\text { sponsored CME } \\
\text { events outside } \\
\text { the workplace }\end{array}$} & Never & $158(53)$ & $91(69)$ & $67(40)$ & \multirow{3}{*}{$<.001$} & $10(25)$ & $148(57)$ & \multirow{3}{*}{$<.001$} \\
\hline & Once to three times a month & $134(45)$ & $40(31)$ & $94(56)$ & & $30(75)$ & $104(4)$ & \\
\hline & One a week or more & $8(3)$ & 0 & $8(5)$ & & 0 & $8(3)$ & \\
\hline \multirow{3}{*}{$\begin{array}{l}\text { Financial } \\
\text { subsidies to } \\
\text { attend CME } \\
\text { events }\end{array}$} & Never & $167(56)$ & $89(68)$ & $78(46)$ & \multirow{3}{*}{$<.001$} & $11(28)$ & $156(60)$ & \multirow{3}{*}{$<.001$} \\
\hline & Once to three times a month & $127(42)$ & $42(32)$ & $85(50)$ & & $29(73)$ & $98(38)$ & \\
\hline & One a week or more & $6(2)$ & 0 & $6(4)$ & & 0 & $6(2)$ & \\
\hline
\end{tabular}

\section{Discussion}

Most of the participants (223, 74\%) met with PRs frequently, which is concerning. However, this is almost similar to other international studies; for example $77 \%-84 \%$ of German physicians were visited at least once a week $(18,19)$ and up to $95 \%$ according to another study by De Ferrarai A, et al. (20). In our study the majority of physicians believe that PRs did not influence their practice, but did influence other physicians. This concept is difficult to prove among our participants due to the nature of our study, which is not designed to assess this question. However, it has been reported in many other studies (21-23). Never the less, there are several studies documenting the negative effect of PR on physicians clinical practice $(5,24,25)$.

More than 135 (45\%) physicians agreed that PRs provided accurate information about new drugs and $142(47 \%)$ agreed about the accuracy of information for old drugs. This is similar to a previous study by Leib et al. (19) where $43 \%$ of German physicians believed PRs provided adequate and accurate information. Of greater concern in our study is that $239(80 \%)$ of physicians agreed that PRs use promotional techniques in their approach and 251 (84\%) affirmed the need for the presence of an expert physician at PR presentations to ensure factual accuracy.
In this study, more than two thirds of our physicians $(192,64 \%)$ received gifts, most of which were industry sponsored CME events. This also has been reported in other studies where $31 \%-98 \%$ received gifts, and $32 \%-$ $85 \%$ received material, equipment or drugs sample for professional use $(16,20,26)$. Prescribing behaviors have been shown in many studies to be influenced by this practice, despite denials by participating physicians (17). Lurie et al. (27) found that in one institution $25 \%$ of internal medicine faculty and $32 \%$ of residents reported that they had changed their practice at least once in the preceding year because of a discussion with a PR.

Approximately two thirds of participants (192,64\%) had been invited to activities sponsored by pharmaceutical companies - in some cases to be promotional (7) - and studies have shown the prescribing pattern of physicians changed after they attend such conferences (17). One study of psychiatry residents (28) showed the influence increased to 50\%. Many physicians (193, 63\%) believe that PRs contribute to academic activities. Two-thirds of physicians (184 61\%) denied any influences of PRs on their prescribing patterns. This result concurs with Saito et al. (16) where $69 \%$ of physicians denied any impact from PRs on their prescribing behaviour. However, this 


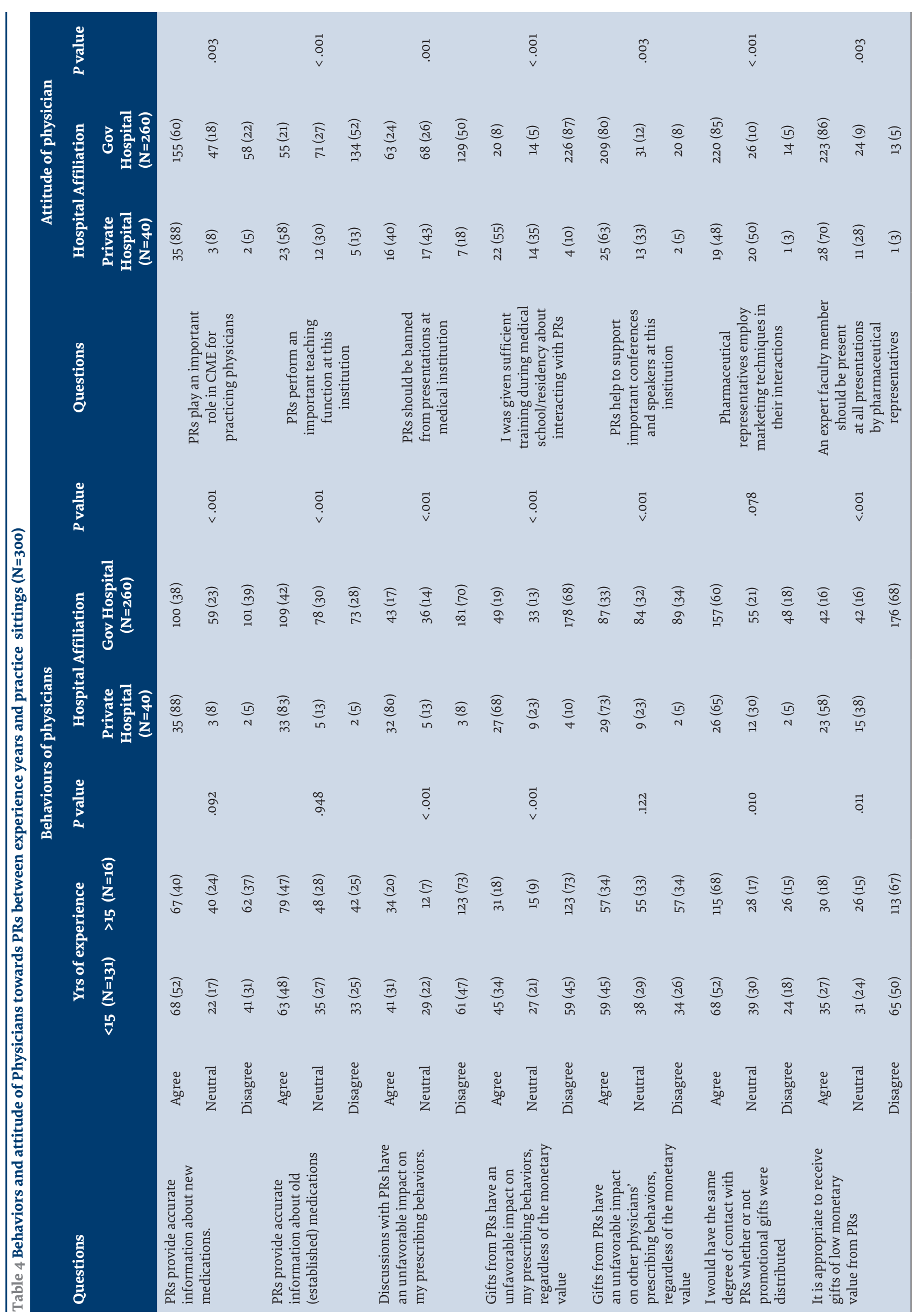


finding needs to be examined carefully and objectively. The majority of the respondents $(230,77 \%)$, did not receive any education in how to deal with PRs or ethical impact of such relationships, and this issue should be addressed as early as medical school.

These issues need to be regulated. In some countries, the code of marketing also regulates the function of drugs representative. For example, in Canada, this code requires $P R s$ to provide full and factual information on products without misrepresentation or exaggeration. Representatives' statements must be accurate and complete and must not be misleading, either directly or by implication (29). In the USA, the Pharmaceutical Research and Manufacturers of America (PhRMA), in 2009, implemented a new code of conduct governing physician-industry relationships among its members (30). This code states that these interactions must benefit patients and enhance the field of medicine. It also discourages pharmaceutical companies from giving physicians gifts that do not carry benefit to patients.

\section{Limitations}

The limitation of the study is that respondent bias may be present, as physicians were more likely to answer the survey in a more ethically acceptable manner. We tried to minimize this issue by conducting the survey completely anonymously. In addition, we did not assess the effect of
PRs on the cost of prescribing medication because of the nature of our study design. However, this issue has been studied before (31-33).

\section{Conclusion/recommendations}

The frequent meetings and the use by PRs of promotional techniques such as drug samples, gifts and CME events, are concerning. PRs have shown they are involved in academic activities by sponsoring CME events and by sponsoring speakers to such events who may have an influence on physicians and their prescribing behaviours. This study did not cover the influence of PR activity on the actual prescribing of the physicians concerned, but there is an urgent need for future research to assess the impact and influence of this involvement PR on medical practice in Saudi Arabia.

Currently, we do not know the extent of this relationship and its effects on healthcare or healthcare providers. Physicians should be educated to deal with PRs early in their careers; possibly at medical school. The relationship between the pharmaceutical industry and physicians must be regulated by institutions and local health professional organizations to assure the best healthcare is being provided to patients.

Funding: None.

Competing interests: None declared.

\section{Attitudes et comportements des médecins vis-à-vis du lien avec l'industrie pharmaceutique en Arabie saoudite}

\section{Résumé}

Contexte : Le lien et les interactions entre les médecins et l'industrie pharmaceutique peuvent avoir une incidence sur la prise en charge des patients. En effet, ce lien peut influencer la pratique d'un médecin. On estime que ce type d'interactions est courant chez les médecins en Arabie saoudite.

Objectifs : La présente étude a été menée afin d'évaluer la fréquence de ces liens ainsi que les attitudes et les comportements des médecins vis-à-vis de ces interactions.

Méthodes : La présente étude transversale consistait en un questionnaire rempli par des médecins en exercice dans quatre centres de soins tertiaires publics et privés à Riyadh (Arabie saoudite). Le questionnaire portait sur la fréquence des réunions avec des représentants de compagnies pharmaceutiques et des cadeaux reçus. Il s'intéressait aussi aux attitudes et comportements des médecins vis-à-vis de ces représentants.

Résultats : $\mathrm{Au}$ total, 300 questionnaires remplis ont été collectés. Parmi les médecins interrogés, $223(74,3 \%)$ rencontraient un représentant de compagnie pharmaceutique une à trois fois par mois. Non moins de 191 médecins (64\%) ont admis recevoir des cadeaux. Plus des deux tiers des médecins - à savoir 192 (63\%) ont été invités à des activités parrainées par les compagnies pharmaceutiques. Parmi les médecins interrogés, 239 (80 \%) s'accordaient pour affirmer que les représentants de ces compagnies utilisaient des techniques promotionnelles dans leur approche et 251 (84\%) d'entre eux insistaient sur la nécessité pour les médecins experts d'assister aux présentations des représentants afin de corriger les faits mentionnés.

Conclusions : Les réunions fréquentes entre les médecins et les représentants des compagnies pharmaceutiques, ainsi que l'utilisation de techniques promotionnelles par ces derniers, sont inquiétantes. De prochaines études devraient évaluer l'impact de cette implication sur l'exercice de la médecine et sur la prescription de médicaments en Arabie saoudite. 


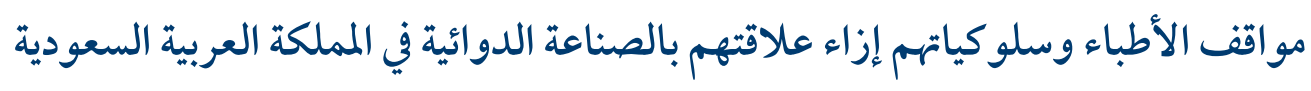
سلمان باهمام، سهيل عسيري، ياسر الجحدلي، سليم باهارون، عدنان الشيخ، ماجد الغامدي، عبد الله الحربي، حدان الجحدلي الخلاصة

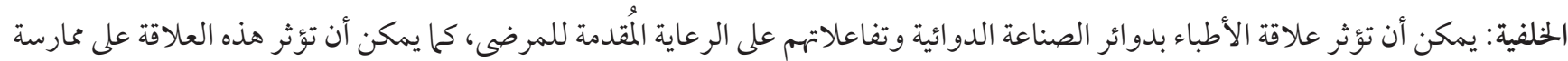

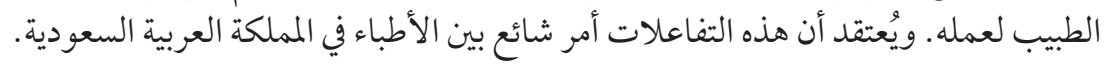
الأهداف: هدفت الدراسة إلى تقييم تو اتُ هذه العلاقات ومواقف الأطباء وسلو كياتهم إزاءها.

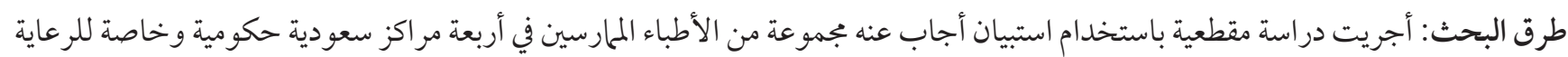

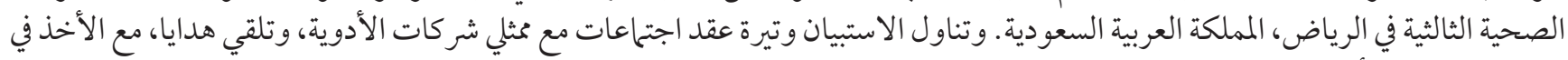

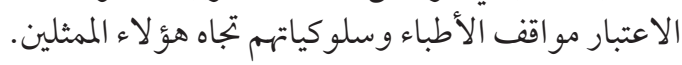

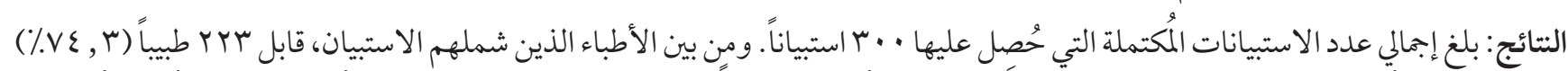

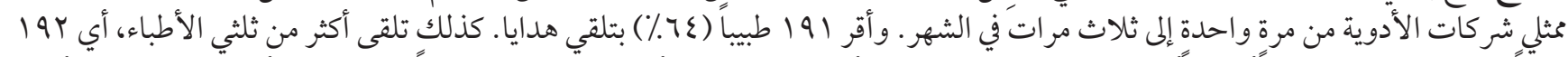

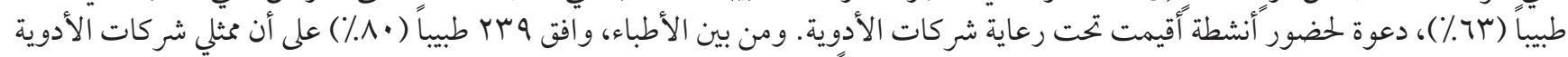

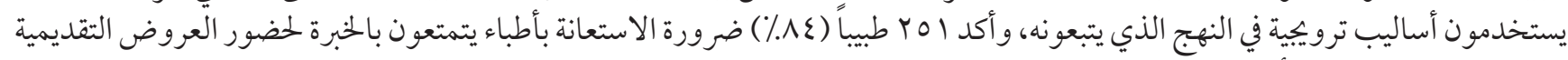

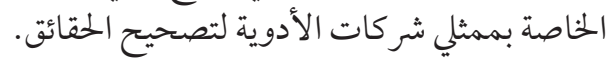

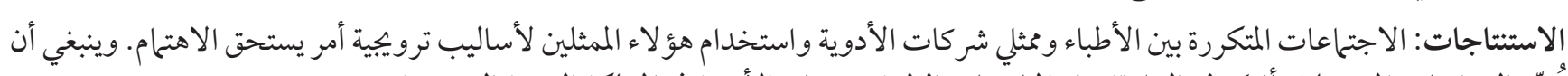

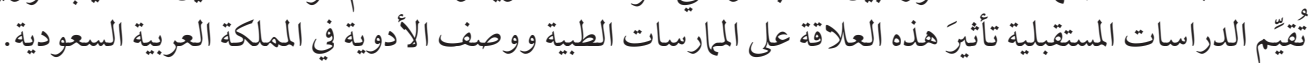

\section{References}

1. Fickweiler F, Fickweiler W, Urbach E. Interactions between physicians and the pharmaceutical industry generally and sales representatives specifically and their association with physicians' attitudes and prescribing habits: a systematic review. BMJ Open. 2017;7(9):e016408.

2. Komesaroff PA. Ethical issues associated with gifts provided to physicians by the pharmaceutical industry. Intern Med J. 2010;40(5):321-2.

3. Beran RG. Doctors and pharmaceutical industry. Med Law. 2009;28(3):541-55.

4. Lexchin J. What information do physicians receive from pharmaceutical representatives? Can Fam Physician. 1997;43:941-5.

5. Wazana A. Physicians and the pharmaceutical industry: is a gift ever just a gift? JAMA. 2000;283(3):373-80.

6. FOUNDATION KF. National Survey of Physicians Part II: Doctors and Prescription Drugs. Mar 31, 2002.

7. Campbell EG, Gruen RL, Mountford J, Miller LG, Cleary PD, Blumenthal D. A national survey of physician-industry relationships. N Engl J Med. 2007;356(17):1742-50.

8. Fadlallah R, Alkhaled L, Brax H, Nasser M, Rajabbik MH, Nass H, et al. Extent of physician-pharmaceutical industry interactions in low- and middle-income countries: a systematic review. Eur J Public Health. 2018;28(2):224-30.

9. Fadare JO, Oshikoya KA, Ogunleye OO, Desalu OO, Ferrario A, Enwere OO, et al. Drug promotional activities in Nigeria: impact on the prescribing patterns and practices of medical practitioners and the implications. Hosp Pract (1995). 2018;46(2):77-87.

10. Nissanholtz-Gannot R, Yankellevich A. Regulating the relationship between physicians and pharmaceutical companies: a qualitative and descriptive analysis of the impact of Israeli legislation. Isr J Health Policy Res. 2017;6(1):45.

11. Makowska M. Polish physicians' cooperation with the pharmaceutical industry and its potential impact on public health. PLoS One. 2017;12(9):e0184862.

12. Ammous A, Bou Zein Eddine S, Dani A, Dbaibou J, El-Asmar JM, Sadder L, et al. Awareness and attitudes of the Lebanese population with regard to physician-pharmaceutical company interaction: a survey study. BMJ Open. 2017;7(3):e013041.

13. Kamal S, Holmberg C, Russell J, Bochenek T, Tobiasz-Adamczyk B, Fischer C, et al. Perceptions and Attitudes of Egyptian Health Professionals and Policy-Makers towards Pharmaceutical Sales Representatives and Other Promotional Activities. PLoS One. 2015;10(10):e0140457.

14. Alosaimi FD, Al Kaabba A, Qadi M, Albahlal A, Alabdulkarim Y, Alabduljabbar M, et al. Physicians' attitudes towards interaction with the pharmaceutical industry. East Mediterr Health J. 2015;20(12):812-9.

15. Makowska M. Interactions between doctors and pharmaceutical sales representatives in a former communist country. The ethical issues. Camb Q Healthc Ethics. 2014;23(3):349-55.

16. Saito S, Mukohara K, Bito S. Japanese practicing physicians' relationships with pharmaceutical representatives: a national survey. PLoS One. 2010;5(8):e12193. 
17. Physicians and the pharmaceutical industry. American College of Physicians. Ann Intern Med. 1990;112(8):624-6.

18. Lieb K, Brandtonies S. A survey of german physicians in private practice about contacts with pharmaceutical sales representatives. Dtsch Arztebl Int. 2010;107(22):392-8.

19. Lieb K, Scheurich A. Contact between doctors and the pharmaceutical industry, their perceptions, and the effects on prescribing habits. PLoS One. 2014;9(10):e110130.

20. De Ferrari A, Gentille C, Davalos L, Huayanay L, Malaga G. Attitudes and relationship between physicians and the pharmaceutical industry in a public general hospital in Lima, Peru. PLoS One. 2014;9(6):e100114.

21. Morgan MA, Dana J, Loewenstein G, Zinberg S, Schulkin J. Interactions of doctors with the pharmaceutical industry. J Med Ethics. 2006;32(10):559-63.

22. Rutledge P, Crookes D, McKinstry B, Maxwell SR. Do doctors rely on pharmaceutical industry funding to attend conferences and do they perceive that this creates a bias in their drug selection? Results from a questionnaire survey. Pharmacoepidemiol Drug Saf. 2003;12(8):663-7.

23. Korenstein D, Keyhani S, Ross JS. Physician attitudes toward industry: a view across the specialties. Arch Surg. 2010;145(6):570-7.

24. Ziegler MG, Lew P, Singer BC. The accuracy of drug information from pharmaceutical sales representatives. JAMA. 1995;273(16):1296-8.

25. Othman N, Vitry A, Roughead EE. Quality of pharmaceutical advertisements in medical journals: a systematic review. PLoS One. 2009;4(7):e6350.

26. Alssageer MA, Kowalski SR. What do Libyan doctors perceive as the benefits, ethical issues and influences of their interactions with pharmaceutical company representatives? Pan Afr Med J. 2013;14:132.

27. Lurie N, Rich EC, Simpson DE, Meyer J, Schiedermayer DL, Goodman JL, et al. Pharmaceutical representatives in academic medical centers: interaction with faculty and housestaff. J Gen Intern Med. 1990;5(3):240-3.

28. Hodges B. Interactions with the pharmaceutical industry: experiences and attitudes of psychiatry residents, interns and clerks. CMAJ. 1995;153(5):553-9.

29. Lexchin J. PMAC code of marketing practices. JAMC. 1999;160(11):1556.

30. (PhRMA) TPRaMoA. Code on Interactions with Healthcare Professionals. http://phrma-docsphrmaorg/sites/default/files/pdf/ phrma_marketing_code_2008pdf [Internet]. January 2009. . Available from: http://phrma-docs.phrma.org/sites/default/files/pdf/ phrma_marketing_code_2008.pdf.

31. Spurling GK, Mansfield PR, Montgomery BD, Lexchin J, Doust J, Othman N, et al. Information from pharmaceutical companies and the quality, quantity, and cost of physicians' prescribing: a systematic review. PLoS Med. 2010;7(10):e1000352.

32. Brax H, Fadlallah R, Al-Khaled L, Kahale LA, Nas H, El-Jardali F, et al. Association between physicians' interaction with pharmaceutical companies and their clinical practices: A systematic review and meta-analysis. PLoS One. 2017;12(4):e0175493.

33. Guldal D, Semin S. The influences of drug companies' advertising programs on physicians. Int J Health Serv. 2000;30(3):585-95. 